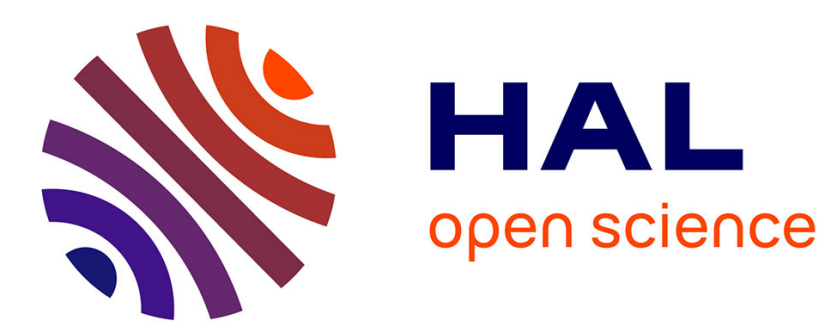

\title{
Microstructural changes caused by penetration of shaped charge jet into steel targets
}

\author{
J. Krejcí, J. Brezina, J. Buchar
}

\section{To cite this version:}

J. Krejcí, J. Brezina, J. Buchar. Microstructural changes caused by penetration of shaped charge jet into steel targets. Journal de Physique IV Proceedings, 1994, 04 (C8), pp.C8-313-C8-318. 10.1051/jp4:1994847 . jpa-00253407

\section{HAL Id: jpa-00253407 https://hal.science/jpa-00253407}

Submitted on 1 Jan 1994

HAL is a multi-disciplinary open access archive for the deposit and dissemination of scientific research documents, whether they are published or not. The documents may come from teaching and research institutions in France or abroad, or from public or private research centers.
L'archive ouverte pluridisciplinaire HAL, est destinée au dépôt et à la diffusion de documents scientifiques de niveau recherche, publiés ou non, émanant des établissements d'enseignement et de recherche français ou étrangers, des laboratoires publics ou privés. 


\title{
Microstructural changes caused by penetration of shaped charge jet into steel targets
}

\author{
J. Krejcí, J. Brezina and J. Buchar* \\ Institute of Physics of Materials, ASCR, Zizkova 22, 61662 Brno, Czech Republic \\ * Department of Physics, University of Agriculture, Zemedelská I, 60100 Brno, Czech Republic
}

\begin{abstract}
Resumé: On étudie l'effect de limpact des jets métalliques sur le comportement. Des travaux ont été en trepris sur le comportement d'un acier $(0.37 \mathrm{C}, 0.80 \mathrm{Mn}, 1.04 \mathrm{Cr}, 1.38 \mathrm{Ni}, 0.24 \mathrm{Mo}$ ) et limpact des jets métalliques. La microstructure est examinée par microscopie électronique à balayge.
\end{abstract}

\begin{abstract}
The interaction of the shaped charge jet with low alloyed high strength steels subjected to different heat treatment along with low alloyed bainitic and cast austenitic steel has been studied. The structure affected by jet penetration was evaluated by means of light and scanning electron microscopy and X-ray microanalysis. The microstructural features and their changes are described (perforation surface layer, cracking, adiabatic shear bands etc.)
\end{abstract}

\section{INTRODUCTION}

A shaped charge is a cylinder of an explosive with a conical cavity lined by a thin layer of metal, glass, ceramics etc. [1]. Upon ignition of the explosive, the detonation wave spreads through the explosive engulfing the cavity. The material of the liner is accelerated by high detonation pressure and the metal cone collapses. During this process part of the liner material forms a jet, which moves forward at a very high velocity (typically around $8000 \mathrm{~ms}^{-1}$ ). When a jet strikes the target it induces high pressures, around $30 \mathrm{GPa}$, and forces the target material to flow plastically away from the impact site. Most of papers, dealing with this type of penetration, treat it in the framework of the hydrodynamic concept. This approach evidently overlooks the role of structure, both of the target and of the jet.

A better explanation of the material characteristics effects on jet penetration requires more information on the structural changes caused by the penetrating jet.

The aim of the present paper is the analysis of structure alterations which occur during the penetration of copper jets into steel targets.

\section{EXPERIMENTS}

Experiments were done mainly on low alloyed high strength steel (Czech equivalent of AISI 4340 steel) with composition: $0.37 \mathrm{C}, 0.80 \mathrm{Mn}, 1.04 \mathrm{Cr}, 1.38 \mathrm{Ni}, 0.24 \mathrm{Mo}-$ in $w t \%$. Discs $60 \mathrm{~mm}$ in diameter and 10 $\mathrm{mm}$ thick, were austenitized at $840^{\circ} \mathrm{C}\left(1100^{\circ} \mathrm{C}\right)$, quenched and tempered at different temperatures 
between $180^{\circ} \mathrm{C}$ and $700^{\circ} \mathrm{C}$. Discs were stacked to form a layered target. In a similar way cylinders (diameter $60 \mathrm{~mm}$, length $150 \mathrm{~mm}$ ), used as compact targets, were processed. Heat treatment and some relevant mechanical properties are given in Tab. 1 . Further the low-alloy bainitic steel $(0.13 \mathrm{C}, 0.59 \mathrm{Mn}$, $0.16 \mathrm{Si}, 1.99 \mathrm{Cr}, 0.61 \mathrm{Mo}, 0.15 \mathrm{~V}, 0.023 \mathrm{P}, 0.015 \mathrm{~S}$ - all wt. $\%$ ), Y.S. $=380 \mathrm{MPa}$, UTS $=560 \mathrm{MPa}$ (discs $55 \mathrm{~mm}$ thick) and cast austenitic steel (18/8) were used.

For comparison, perforations caused by solid projectiles $(\mathrm{WC}+\mathrm{Ni})$ in bainitic steel targets were also studied.

The structure was examined by light microscopy, scanning and transmission electron microscopy, $\mathrm{X}$-ray microanalysis and hardness measurement.

\section{RESULTS}

The impact surface of the target and the shape of the entrance opening made by a jet depend on the target material (mechanical) properties. Macroscopic features of perforation can be described as follows. The shape of perforation is wavy, the particular contour depends on target structure and dimensions (Fig. 1).

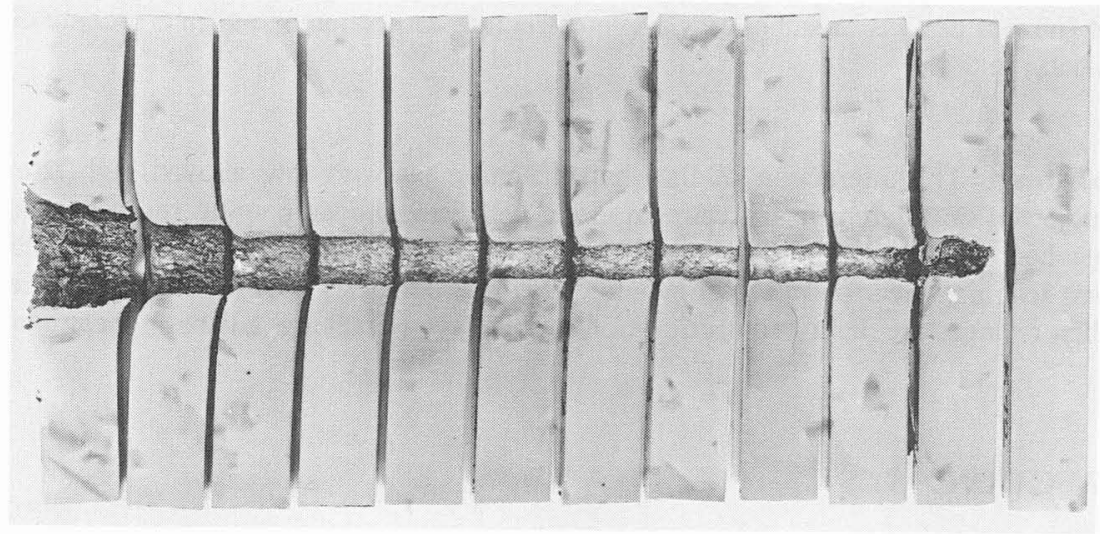

Fig.1 The perforation caused by copper jet in "soft" target. $1 \mathrm{x}$

Penetration depth and volume are in Tab.1. The perforation surface is covered by a layer containing both the target and jet material. Depending on the structure of the target, a very hard layer (up to 900 HV) forms in the vicinity of the perforation surface, Fig.2. This layer was encountered especially in "hard" specimens. Its structure is apparently caused by intense shear deformation and resembles the structure surrounding the core of adiabatic shear bands (ASB) [2]. Macrocracks that appear in the material around the perforation are more frequent in "hard" specimens. The cracks are either inclined to or parallel with the perforation surface. The latter forming on the cylindrical surface with its axis matching to the perforation axis. If these cracks are connected with the perforation surface, then usually mixed material partly fills them. The already existing cracks filled with $\mathrm{Cu}+\mathrm{Fe}$ mixture are later in the process subjected to the stress that cause their opening, Figs 3 and 4. In hard discs, cracks perpendicular to the target axis are sometimes observed under the bottom of incomplete perforation. Hard discs are in a stressed state after the perforation (they often break when cutting is attempted). The hardness of target material is increased, the maximum value and extent of the affected region depend on the structure of target. 


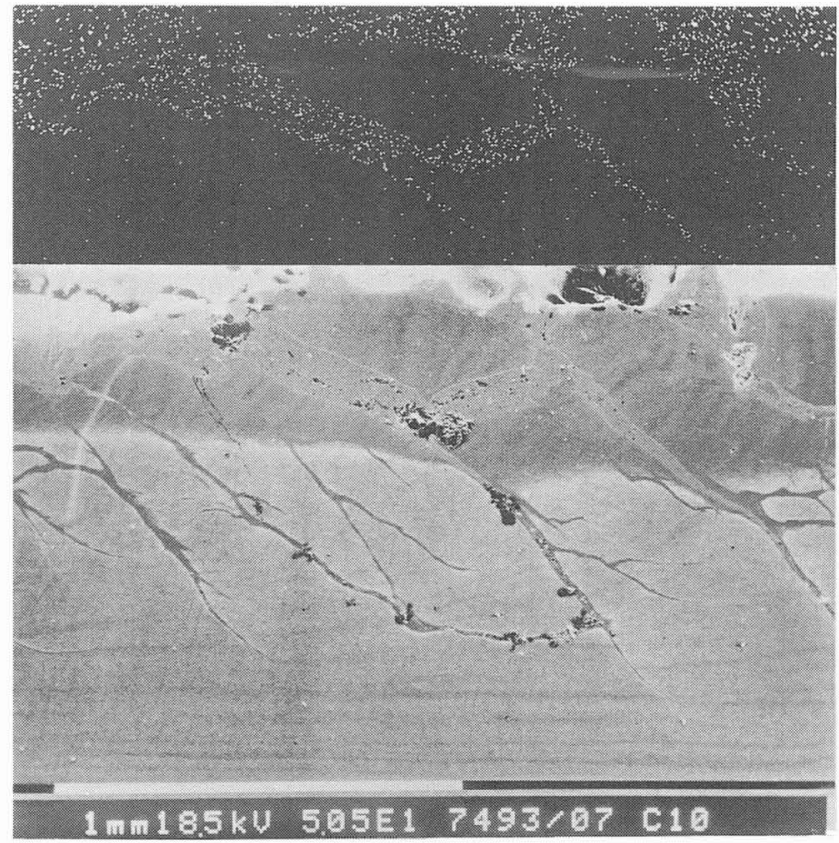

Fig.2. Hard (dark) layer at the perforation surface (bottom) and corresponding mapping in $\mathrm{Cu} \mathrm{K} \alpha$

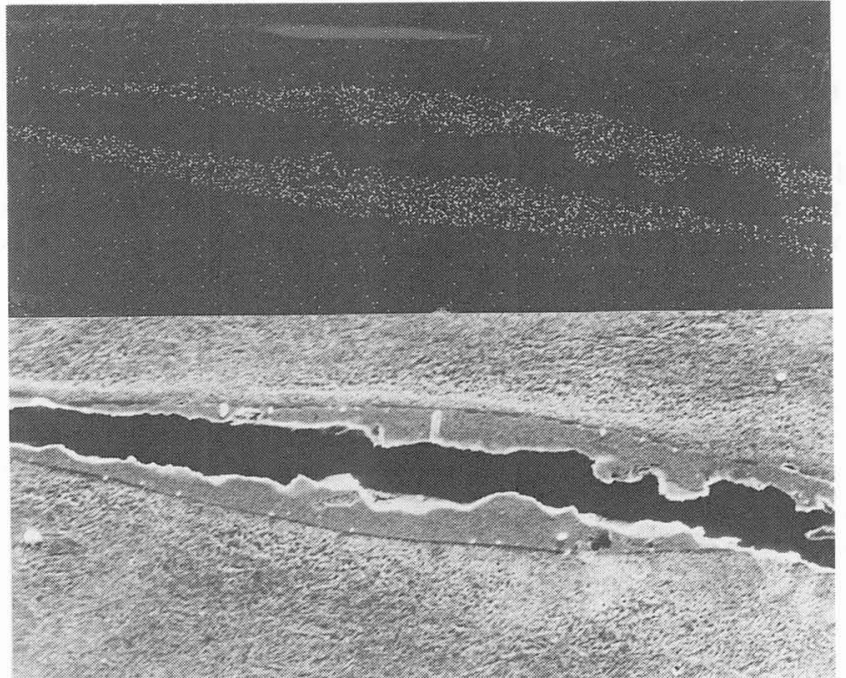

Fig.3. Crack near the perforation filled with $\mathrm{Cu}+\mathrm{Fe}$ alloy subsequently opened (bottom). Corresponding mapping in $\mathrm{Cu} \mathrm{K} \alpha$ line. $500 \mathrm{x}$

Under the bottom of the perforation, the increased hardness gradually falls to the original value. The increase in hardness is larger in "soft" than in "hard" specimens, so that the final value near the perforation is almost identical.

On a finer scale we observed ASB and intense deformation around the perforation, Fig.5. ASB do not necessarily serve as crack nucleation sites. 


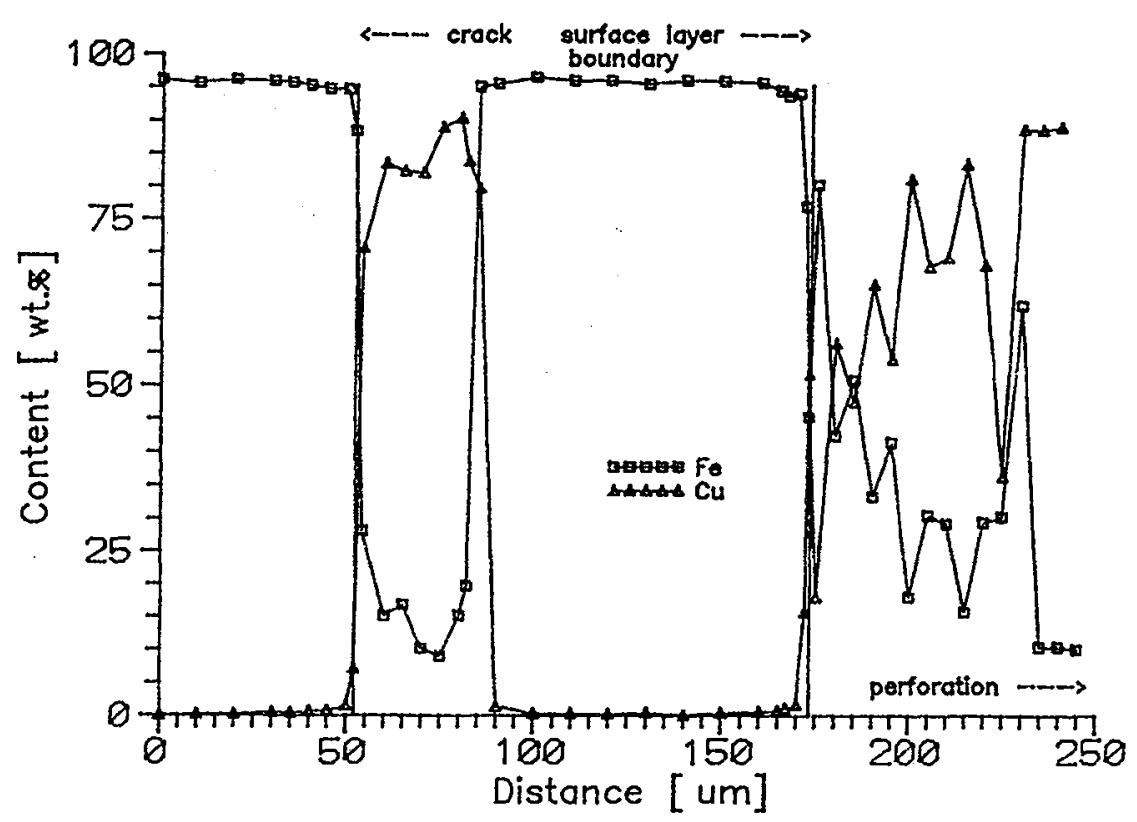

Fig.4. Microanalysis along the line perpendicular to the perforation surface

The thickness, extent and composition of the surface layer containing both jet and target material depend on several factors. Its thickness and extent decrease with target hardness and distance from impact surface (depth of penetration). Its composition varies especially in deep regions of perforation, sometimes even isles of target material can be observed embedded in the mixture matrix (Fig.6). The bottom of the incomplete perforation is covered by a compact layer of mixed $\mathrm{Cu}+$ target material.

\section{Discussion}

The existence and location of the cracks proves that stress waves play an important role in the process of perforation. The dominant mechanism is apparently erosion and friction that produces perforation and the layer containing both target and jet material. Comparing the features of perforation caused by a shaped charge jet with that produced by a solid projectile (WC+Ni), it can be seen that all features are present in both events, and these impacts differ only quantitatively.We can assume that stress waves which propagate in the material with higher velocity than the projectiles (jet or solid) damage the target's material and thus make its penetration easier. Penetration itself is the result of erosion of target (and projectile) material. The process is not completely smooth - the waviness of perforation in compact targets suggest that slow erosion alternate with faster penetration of already damaged material. 
C8-317

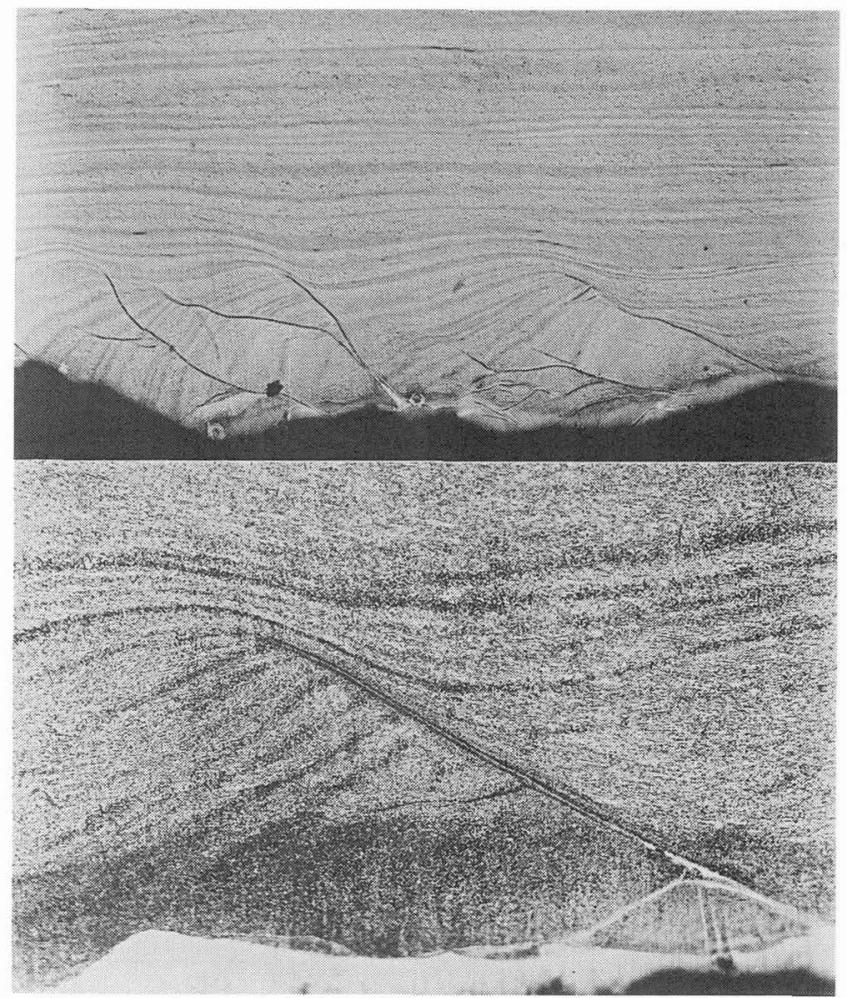

Fig.5. Light microscopy of the region adjacent to the perforation $50 \mathrm{x}$ (top) and $200 \mathrm{x}$ (bottom)

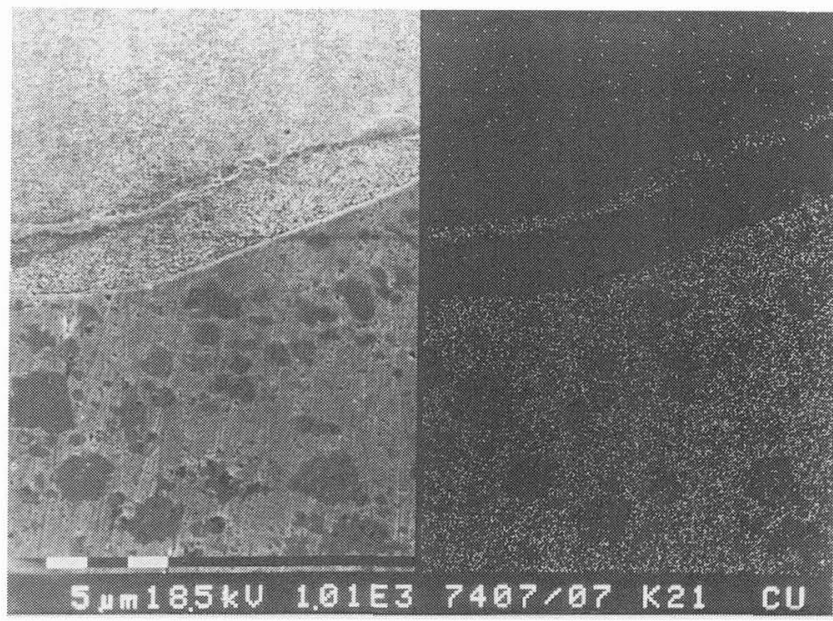

Fig.6. Surface of perforation near the bottom. Target material embedded in the mixed layer and corresponding mapping in $\mathrm{Cu} \mathrm{K \alpha}$ 


\section{References:}

[1] Walters W.P.and Zukas J.A, Fundamentals of Shaped Charges. (John Wiley, New York 1989).

[2] Krejci J. et al., Scripta Metal. et Mater. 27 (1992) 611 - 615

Tab.1 Heat treatment, mechanical properties of the target steel (LAHS) and depth of perforation

\begin{tabular}{|c|c|c|c|c|c|c|}
\hline Austenitization & Tempering & $\begin{array}{l}\mathbf{R}_{\mathrm{p} 0.02} \\
{[\mathrm{MPa}]}\end{array}$ & $\begin{array}{c}R_{m} \\
{[\mathrm{MPa}]}\end{array}$ & HV10 & $\begin{array}{l}\text { Depth } \\
{[\mathrm{mm}]}\end{array}$ & $\begin{array}{l}\text { Volume } \\
\text { [mm³] }\end{array}$ \\
\hline $840^{\circ} \mathrm{C} / 30^{\prime} / \mathrm{oil}$ & $180^{\circ} \mathrm{C} / 145^{\prime}$ & 1530 & 1978 & 550 & 78 & \\
\hline $840^{\circ} \mathrm{C} / 30^{\prime} /$ oil & $250^{\circ} \mathrm{C} / 145^{\prime}$ & 1472 & 1732 & 480 & 81 & \\
\hline $840^{\circ} \mathrm{C} / 30^{\prime} /$ oil & $320^{\circ} \mathrm{C} / 45^{\prime}$ & 1450 & 1620 & 477 & 88 & \\
\hline $840^{\circ} \mathrm{C} / 30^{\prime} /$ oil & $400^{\circ} \mathrm{C} / 45^{\prime}$ & 1402 & 1518 & 439 & 90 & \\
\hline $840^{\circ} \mathrm{C} / 30^{\prime} /$ oil & $500^{\circ} \mathrm{C} / 35^{\prime}$ & 1220 & 1256 & 389 & 96 & \\
\hline $840^{\circ} \mathrm{C} / 30^{\prime} /$ oil & $600^{\circ} \mathrm{C} / 35^{\prime}$ & 1073 & 1104 & 345 & 97 & \\
\hline $840^{\circ} \mathrm{C} / 30^{\prime} /$ oil & $650^{\circ} \mathrm{C} / 35^{\prime}$ & 888 & 929 & 287 & 105 & \\
\hline $840^{\circ} \mathrm{C} / 30^{\prime} / \mathrm{oil}$ & $700^{\circ} \mathrm{C} / 35^{\prime}$ & 747 & 867 & 270 & 106 & 4400 \\
\hline $1100^{\circ} \mathrm{C} / 30^{\prime} / \mathrm{oil}$ & $180^{\circ} \mathrm{C} / 145^{\prime}$ & 1377 & 1812 & 600 & 85 & 2819 \\
\hline $840^{\circ} \mathrm{C} / 30^{\prime} /$ oil & $180^{\circ} \mathrm{C} / 145^{\prime}$ & & & 607 & 107 & 2345 \\
\hline $840^{\circ} \mathrm{C} / 30^{\prime} / \mathrm{oil}$ & $400^{\circ} \mathrm{C} / 45^{\prime}$ & comp & target & 512 & 115 & \\
\hline $840^{\circ} \mathrm{C} / 30^{\prime} / \mathrm{oil}$ & $700^{\circ} \mathrm{C} / 35^{\prime}$ & comp & target & 283 & 126 & 4241 \\
\hline \multirow{2}{*}{\multicolumn{4}{|c|}{ Compact targets with mixed structure }} & 400 & 108 & 3448 \\
\hline \multirow{7}{*}{\multicolumn{4}{|c|}{$\begin{array}{c}\text { Mixed layered targets: } \\
\text { soft } \rightarrow \text { hard } \\
\text { hard } \rightarrow \text { soft } \\
\text { hard } \rightarrow \text { hard } \\
\text { soft } \rightarrow \text { hard } \\
\text { hard } \rightarrow \text { soft } \\
\text { hard } \rightarrow \text { medium } \rightarrow \text { hard }\end{array}$}} & & & \\
\hline & & & & 390 & 87 & 5107 \\
\hline & & & & 434 & 102 & 3788 \\
\hline & & & & 569 & 78 & \\
\hline & & & & 404 & 81 & 4634 \\
\hline & & & & 410 & 97 & 2878 \\
\hline & & & & 492 & 88 & \\
\hline
\end{tabular}

